\title{
PRZEGLĄD BIBLIOGRAFICZNY
}

\author{
ANALECTA CRACOVIENSIA
}

1986, t. XVIII

Chłąd St. ks., Theatron (1 Kr 4, 9). Sytuacja chrześcijanina w świecie, 185 - 194; Chmiel J. ks., Die Interpretation des paulinischen hōs mè im 1 Kor 7, 29-31; 197 - 204; Jelonek T. ks., Problem autorstwa Listu do Hebrajczyków, 205 - 240; Mayberger P., Zur „Dulcedo Dei” im Alten Testament, 167 - 184; Mendecki N. ks., Diaspora babilońska - amoryci $i$ saboryci, $245-250$

\section{ATENEUM KAPEAŃSKIE}

1986 , t. 107, z. $2-3$

Brändle Fr. OCD, Historia Józefa $i$ jej wpływy na teologiẹ świętojózefowa wedtug Ewangelii sw. Mateusza, 227 - 238

1986 , z. 3

\section{COLLECTANEA THEOLOGICA}

Krawczyk R., ks., Transcendencja jako przymiot Boga w myśli Starego Testamentu, 35 - 42; Mendecki N. ks., Filistyni, Aramejczycy i Kananejczycy $w$ drugiej połowie tysiaclecia przed Chrystusem, 43 - 46; Mędala St. CM, Biblia i informatyka, $173-180$

\section{HOMO DEI}

1986, 2. 2

Wójtowicz K. CR, Ostatnie pouczenia Zmartwychwstałego (Łk 22, 44 - 53), $90-93$

1987, z. 2

JASNA GORA

Grzybek St. ks., Najświętsza Maryja Panna w Piśmie świętym, 33 - 40

\section{MATERIAEY PROBLEMOWE}

1986, z. 9

Banak J. ks., Wprowadzenie biblijne do sakramentu kapłaństwa, 18 - 20 1986, z. 10

Czajkowski M. ks., Funkcja profetyczno-krytyczna Kościoła przepowiadajacego $w$ świetle Biblii, 95 - 103; Tyburczy A., Małźnénstwa $w$ historii Izraela, Ideał i rzeczywistość, 42 - 47; tenże, Spotkania $z$ Pismem swiętym - „Stowo natchnione”, 48 - 54

1986, z. 11

Banak J. ks., Sakrament chorych - Wprowadzenie biblijne, 31 - 32;

Tyburczy A., Jezus $i$ kobiety, $60-64$ 